\title{
Rethinking farmer knowledge from soil to plate through narrative inquiry: An agroecological food systems perspective
}

\author{
Eric S. Bendfeldt a \\ Virginia Cooperative Extension \\ Maureen McGonagle ${ }^{b}$ and Kim Niewolny ${ }^{c *}$ \\ Virginia Tech
}

Submitted December 21, 2020 / Revised April 12 and July 2, 2021 / Accepted July 2, 2021 /

Published online December 3, 2021

Citation: Bendfeldt, E. S., McGonagle, M., \& Niewolny, K (2021). Rethinking farmer

knowledge from soil to plate through narrative inquiry: An agroecological food systems perspective. Journal of Agriculture, Food Systems, and Community Development, 11(1), 137-151.

https://doi.org/10.5304/jafscd.2021.111.012

Copyright (C) 2021 by the Authors. Published by the Lyson Center for Civic Agriculture and Food Systems. Open access under CC-BY license.

\begin{abstract}
This paper illustrates how farmer knowledge is generatively constructed and framed within an agroecological context to address the complexities of our food system more fully. For some, farmer knowledge is a hidden asset below the surface that acts as a reserve for sustaining and fortifying food

${ }^{a}$ Eric S. Bendfeldt, Extension Specialist, Community Viability, Virginia Cooperative Extension, School of Plant and Environmental Sciences, Virginia Tech; 2322 Blue Stone Hills Drive, Suite 140; Harrisonburg, Virginia 22801 USA; +1-540232-6006; ebendfel@,vt.edu

b Maureen McGonagle, M.S., Department of Agricultural, Leadership, and Community Education, Virginia Tech; 214 Litton-Reaves Hall; 175 West Campus Drive (MC0343); Blacksburg, Virginia 24061 USA; mqm138@,vt.edu

c* Corresponding author: Kim L. Niewolny, Ph.D., Associate Professor and Director, Center for Food Systems and Community Transformation, Department of Agricultural, Leadership, and Community Education, Virginia Tech; 282 Litton-Reaves Hall (MC0343); Blacksburg, Virginia 24061 USA; +1-540-231-5784; niewolny@,vt.edu
\end{abstract}

system possibilities. We interviewed 12 selfidentified smallholder farmers in Virginia using narrative inquiry as a dynamic methodology to explore the rhizomatic quality and mycorrhizal nature of smallholder farmers' knowledge and experiences of soil, conservation, and place. The narrative inquiry method offered a participatory research approach to analyze how farmers perform their work in ways that extend across and are entangled with other domains of the food system that reflect agroecological values. Five primary themes were identified from the narrative inquiry data analysis by drawing upon the whole measures of community food systems as a values-based framework. Our findings illustrate how farmer praxis is reflective of and influenced by the

\section{Funding Disclosure}

This project was generously funded and supported by a Community Viability grant from Virginia Tech's Department of Agricultural, Leadership, and Community Education, the Agua Fund, and Virginia Cooperative Extension. 
ecological and sociopolitical ethos of land, food, health, and liberation. For scholar-practitioners, this research emphasizes the current claim for reevaluating and reconceptualizing research and outreach responses to mounting food system crises. The construction and expansion of farmer knowledge are not linear but rhizomatic and mycorrhizal in quality; therefore, scholarpractitioner responses to understanding and engaging with farmer knowledge systems should be amenable to a diversity of culturally dynamic systems of knowing that embody socio-eco relations and networks. Like others, we argue that an overemphasis on essentialist "best practices" and technocratic problem-solving does not adequately help us see these generative possibilities from soil to plate. Thus, we recommend that food system practitioners and researchers emphasize engaged listening, storytelling, and generative- not extractive-approaches as an epistemological frame for expanding our understanding of agroecology and food systems change.

\section{Keywords}

Agroecology, Epistemology, Farmer Knowledge, Food Systems, Narrative Inquiry, Rhizomatic, Mycorrhizal, Systems Thinking

\section{Introduction and Literature Review}

Farmers play a vital role as educators and movement makers within our food and farming systems. Over the last several decades, smallholder farmer knowledge has been increasingly valued in grassroots, nonprofit, governmental, and academic circles for the creation and leadership of social movement networking, policy recommendations, and food system transformation strategies for sustainability and food justice (Alkon \& Agyeman, 2011; Brook \& McLachlan, 2008; Carr \& Wilkinson, 2005; DuPuis et al., 2011; Gliessman, 2018; Hassanein, 1999; Laforge \& Levkoe, 2018; Montenegro de Wit \& Iles, 2016; Neef \& Neubert, 2011; Pretty, 2002). Agroecological principles and practices rooted in indigenous knowledge networks have emerged in the Global South and North to address the social, economic, environmental, and political challenges of local agricultural and food systems (Altieri, 2000; Holt-Gimenéz, 2006;
Méndez et al., 2012; Montenegro de Wit, 2021). Montenegro de Wit and Iles (2016) encourage extending agroecology's social, political, cultural, environmental, and ethical influence to impact science and fortify legitimacy. Understanding how farmers' knowledge is constructed and framed as agroecological knowledge in a social context is critical in better addressing the diversity, complexities, and vulnerabilities of our agroecosystems.

Zimdahl (2006) argues that farmers are foundational resources of knowledge in agriculture, just as the soil is a quintessential resource for food and fiber production. However, how farmer knowledge is constructed as agroecological knowledge can be undervalued as a resource, much like the soil beneath us, and requires deeper investigation. Gliessman (2018) framed farmer knowledge as inherently co-creative and transdisciplinary; however, this framing does not easily align with the technicalrational discourses and practices in agricultural sciences. Pimbert (2018) posits that more research and careful critiques of how knowledge and epistemologies are constructed, contested, and deconstructed are needed.

Food system efforts are continually evolving; therefore, farmers and practitioners have to constantly adapt to match the idiosyncratic nature of their farms (Lyon et al., 2011). By engaging in a critical reflection process, farmers as practitioners and observers work on challenging the dominant discourses that maintain our present hegemonic systems (Gliessman, 2018; Stepney, 2006) and integrate theoretical and empirical knowledge to tackle the myriad of complex problems that arise in practice (Montenegro de Wit, 2021; Thompson \& Pascal, 2012).

Critical reflection is also relevant to researchers, educators, and technical service providers. Without critical reflection, technical-oriented "best management practice" approaches in food systems and natural resource conservation work are valorized, and systemic change is viewed as logical, linear, and sequential. The privileging of essentialist and technical-rational discourses and practices in agricultural science reifies a strong tendency to flatten and distill complex systems processes into a suite of best management practices (BMPs) and simple equations (Arnold \& Wade, 2017; Church et 
al., 2020; Laws, 2017). Understanding best management practices and how these practices fit in individual farm operations can increase access to federal and state cost-share programs and technical services and address specific conservation objectives. However, an overemphasis on technocratic problem solving apart from an overall systems approach does not adequately bring to light the interdependence and depth of socio-eco relations within food and agriculture (Galt, 2016; Pimbert, 2017; Pimbert, 2018). Exclusively focusing on BMPs and implementation of practices for conservation separate from a broader food and farm context, for example, can limit peer-to-peer education learning, barely scratch the surface of farmers' complex knowledge base, and overlook the deeply rooted hidden assets of resiliency, sustainability, and social activism that are embedded in farmer's everyday lives.

Farmers' experiences, context, and values inform who they are as knowledge makers, systems thinkers, and practitioners (Pimbert, 2018; Schon, 1983). We argue in this paper that an overemphasis on essentialist and technocratic problem solving does not adequately recognize and value farmers' social-ecological knowledge of the often-hidden soil-to-plate complexities of their farms and broader food systems. Additionally, the pervasive neoliberal framing within government and the food system inherently weakens research, limits educators and conservationists' ability to build durable work relationships with farmers, minimizes opportunities for listening, and constrains food and farm system possibilities. Hence, we argue that storytelling and narrative inquiry demonstrate how smallholder farmer knowledge is social-ecological in context with non-linear rhizomatic and mycorrhizal qualities (Deleuze \& Guattari, 1987; Tedersoo et al., 2020).

\section{Farmer Knowledge as Rhizomatic and Mycorrhizal}

This research was initiated with Virginia farmers to better understand their experiences, contexts, and relationships to soil, conservation, and place and how agroecological principles and practices intersect with individual experiences, contexts, and values. Farmers play a crucial role in cultivating and nurturing soil and the ecological relationships within a farming system. We argue that our most paramount challenges (e.g., degradation and depletion of natural resources) cannot simply be "solved" by technical and rational "best practices" alone but must be addressed through culturally dynamic systems of knowing that embody socioeco relations and networks that are generative and complementary with life-affirming possibilities.

As a life-affirming possibility, we use two agroecological terms common to plant and soil community dynamics: rhizome and mycorrhizae. These terms are used as a metaphoric shift for the nuanced complexity and depth of farmers' knowledge that may be hidden within food and farm discourses and require more than surface-level inquiry (Deleuze \& Guattari, 1987; Niewolny \& D’Adamo-Damery, 2016; Tedersoo et al., 2020). This metaphoric shift emphasizes that farmer knowledge is critical to human and systems ecology (Gliessman, 2017).

Rhizomes are underground plant stems that continually grow and explore the soil surface through lateral shoots and adventitious roots to bolster a plant's food reserve (Evert, 2006). Deleuze and Guattari (1987) described a rhizome as a metaphor to explain how knowledge can be generative and structurally significant-not linear and reductionist. Rhizome growth and expansion allow new assemblages and networked possibilities in unexpected relational ways and spaces (Deleuze \& Guattari, 1987, p. 7).

The second term, mycorrhiza, describes the mutually beneficial relationship developed between a plant root and fungi in the soil. Mycorrhizal fungi are specialized and serve a mutually beneficial role in extending plant roots' reach and assimilative capacity to take in nutrients, water, and environmental information in exchange for carbon and sugars. Like farmers' social-ecological networks and associations, the plant root-fungus association is difficult to see without digging deeper, but the association is symbiotic and significant to structure and survival (Magdoff \& van Es, 2018, p. 16; Sylvia, 2005).

Rhizomes and mycorrhizae function as socioeco metaphors for farmer knowledge, an ecosystem of enmeshed relationships and exchanges 
relevant to soil, food, health, and liberation. Comparably, farmers have abundant, complicated, and distributed roots with context, experiences, and assimilated values that may be hidden but embody who they are (Kirschenmann, 2010). From an agroecological perspective, relationships and exchanges have multiple functions and cannot simply be excavated and isolated from one another. Thus, rhizomes and mycorrhizae as agroecological metaphors help conceptualize the networks, exchanges, and associations critical to creating and constructing farmer knowledge and epistemological possibilities in the food system.

\section{Conceptual Framework}

Interest in soil health education and implementation as an agroecological principle and practice has increased significantly in Virginia and across the world (Karlen \& Rice, 2015; Lal, 2016; USDA NRCS, 2018). Soil health is foundational to proper life-giving ecosystem functions (Magdoff \& Van Es, 2010). Soil health, because of its intersection with the chemical, physical, and biological properties of the soil ecosystem, served as a starting point for the study project. Our conversations with 12 Virginia farmers deepened our understanding of how farmers construct and contest knowledge based on personal experiences, seen and unseen influences, values, and their practices in the food system. Our conceptual framework emphasizes how farmer perspectives and conservation practices reflect and influence their broader ecological and socio-political ethos of land, food, health, and liberation (Pimbert, 2018).

We drew upon Whole Measures for Community Food Systems (Abi-Nadar et al., 2009) as a dialogical framework of farmer knowledge because it incorporates the value of sustainable farmland and natural resources and is intersectional, dynamic, and inclusive of other social and ecological values rather than focusing on specific principles and practices. Abi-Nader et al. (2009) defined whole measures as healthy people, food security, sustainable farmland and natural resources, agricultural profitability, thriving economies, justice and fairness, safe and nutritious food and water, and viable communities. We used this whole measure framing as a compatible agroecological approach for culti- vating sustainable, biodiverse farming systems and a basis to thematically code and analyze the intersectional nature of how farmers conceptualize the socio-eco relations of farming, sustainability, and soil health in their local communities.

Researchers and practitioners need to reconsider the notion of best research and management practice to account for and acknowledge nuance, complexity, and social-eco relationships. Listening and storytelling are research methods complementary for understanding knowledge formation that can add depth and texture to the analysis of agroecological systems and practices. Food systems practitioners and researchers should be encouraged to listen and engage in storytelling and narrativebased research to expand spaces for learning the socio-political aspects of agroecology and extending understanding of farmer knowledge.

\section{Applied Research Methods}

\section{Narrative Inquiry}

Narrative inquiry (Clandinin, 2007; Clandinin \& Connelly, 2000) as a dynamic methodology allowed us to explore the generative intersectional rhizomatic and mycorrhizal nature of smallholder farmers' knowledge and experiences in the creation of healthy soil and place. Richmond (2002) defined "narrative" to mean both a process and a product. This inquiry approach and definition of narrative involves treating stories as both a process of reflexivity through storytelling and the products of the storyteller's voice, activity, and performativity (Niewolny \& D'Adamo-Damery, 2016). This inquiry approach acknowledges that people's everyday knowledge informs ecological philosophy and practice. Narrative inquiry allows the farmer an opportunity to craft their own stories through a series of "prompting" questions as a semistructured conversation to emphasize and clarify personal meanings, worldviews, and histories (Ligrani \& Niewolny, 2017; Lyon et al., 2011; Niewolny \& D'Adamo-Damery, 2016).

Forester (1999) used narrative inquiry as a participatory research mechanism to analyze the way practitioners operate in their work lives as an illustration of power and knowledge. The inquiry approach was used in our study to simultaneously 
reveal theory through farmers' direct experiences (Forester, 1999; Peters et al., 2004). Peters et al. (2004, p. 8) stated stories as narratives are "complex and nuanced," opening dialogue and space to enable readers to move beyond the broad generalizations of what "practitioners" do and reach a rich textured understanding that contains a combination of insight, ambivalence, frustration, and hope. Narratives draw specific attention to the values, strategies, hopes, and motivations farmers embody as an everyday lived experience.

Drawing upon Ligrani and Niewolny (2017), Niewolny and D'Adamo-Damery (2016), Lyon et al. (2011), and Peters et al. (2004), this research approach is about attending to the storyteller, appreciating the experience being shared, and not forcing an interpretive agenda, but allowing the story and narrative to unfold for the storyteller, listener, and reader. We understand narratives as a form and space for performative learning and experimentation and exploring possibilities with one another (Law, 2008). For food systems stakeholders, we recommend narratives as a critical form for learning and deepening understanding.

\section{Research Design and Data Collection}

We interviewed 12 self-identified smallholder farmers who live and farm in Virginia for a Soil, Conservation, and Place study project (Table 1). Project participants consented to share their identities and interview stories following an approved Institutional Review Board (IRB) research protocol. Participating farmers had diverse lived experiences and were located in Augusta, Charles City, Chesterfield, Dinwiddie, Grayson, Hanover, Louisa, and Rockingham counties, and the city of

Table 1. Participating Farmers, Type of Production, and Resource Conservation Practices

\begin{tabular}{|c|c|c|c|}
\hline Farmer & Farm Name & Production Type & $\begin{array}{l}\text { Soil and Water Conservation } \\
\text { Practices }\end{array}$ \\
\hline Janet Aardema & Broadfork Farm & $\begin{array}{l}\text { Vegetables (certified naturally } \\
\text { grown), naturally leavened hearth- } \\
\text { baked bread }\end{array}$ & $\begin{array}{l}\text { No-till/low-till, cover crops, pollinator } \\
\text { habitats }\end{array}$ \\
\hline Danny Boyer & Four Winds Farm & Beef, grass-fed and finished & $\begin{array}{l}\text { Managed grazing, alternative water } \\
\text { systems }\end{array}$ \\
\hline Gerald Garber & Cave View Farms & Dairy cows, feed production & $\begin{array}{l}\text { Rotational loafing lots, concrete } \\
\text { stream walkways, stream fencing }\end{array}$ \\
\hline Anne Geyer & AgriBerry Farm & $\begin{array}{l}\text { Raspberries, blueberries, } \\
\text { blackberries (Good Agricultural } \\
\text { Practices [GAP] certified) }\end{array}$ & $\begin{array}{l}\text { Cover cropping, perennial crop } \\
\text { production }\end{array}$ \\
\hline Amy Hicks & Amy's Organic Garden & $\begin{array}{l}\text { Vegetables, cut flowers, and small } \\
\text { fruit (certified organic) }\end{array}$ & $\begin{array}{l}\text { Crop rotation, cover cropping, } \\
\text { pollinator habitats }\end{array}$ \\
\hline CJ Isbell & Keenbell Farm & $\begin{array}{l}\text { Grass-fed beef, pasture-raised } \\
\text { pork, free-range poultry, eggs, and } \\
\text { specialty non-GMO grains }\end{array}$ & $\begin{array}{l}\text { Managed grazing, no-till/low-till } \\
\text { agriculture, cover cropping, crop } \\
\text { rotation, stream exclusions }\end{array}$ \\
\hline Jonathan McRay & Silver Run Forest Farm & Riparian nursery and folk school & Agroforestry/polyculture \\
\hline Mike Phillips & Valley View Farms & $\begin{array}{l}\text { Grass-fed and pastured beef and } \\
\text { formally poultry }\end{array}$ & $\begin{array}{l}\text { No-till, managed grazing, cover } \\
\text { cropping systems }\end{array}$ \\
\hline Robert H. Spiers & Spiers Farm, LLC & Corn, soybeans, grain, tobacco & Cover cropping, no-till/low-till \\
\hline Renard Turner & Vanguard Ranch, Ltd. & $\begin{array}{l}\text { All-natural, free-range meat goats, } \\
\text { squab, and vegetables }\end{array}$ & Cover cropping, managed grazing \\
\hline Ira Wallace & $\begin{array}{l}\text { Southern Exposure Seed } \\
\text { Exchange }\end{array}$ & $\begin{array}{l}\text { Heirloom and open-pollinated vege- } \\
\text { tables, herbs, and flower seeds }\end{array}$ & $\begin{array}{l}\text { Cover-cropping, no-till/low-till, crop } \\
\text { diversification, organic certification }\end{array}$ \\
\hline Philip Witmer & Grazeland Dairy, Inc. & $\begin{array}{l}\text { Dairy cows, hay, small grain, corn, } \\
\text { wheat, soybeans (certified organic) }\end{array}$ & $\begin{array}{l}\text { Rotational grazing, cover cropping, } \\
\text { no-till/low-till, crop rotation }\end{array}$ \\
\hline
\end{tabular}


Harrisonburg. The social backgrounds of participants ranged from emerging to vast farming experience and included various farming methods, systems, and paradigms. We used purposive sampling to obtain a cross-sectional representation of farmers within Virginia's agricultural community (Cresswell, 2008). The purposive sampling identified potential participants based on age, race, and gender; type of farm operation; geographic region; and recognition from peers, technical service providers (i.e., USDA-NRCS, Soil and Water Conservation Districts), or Extension educators for soil and natural resource conservation. A recruitment letter describing the project and its proposed objectives was shared with the research team and their network of agricultural contacts, associations, advisory boards, and technical service providers. The selected farm operations included but were not limited to: small dairies ( $<100$ cows and $<100$ acres); small dairy/beef plus poultry operations; small ( $<25$ acres) produce operations; grain producers; cotton/tobacco producers; and mixed animal/produce operations.

The 12 farmers were interviewed with semistructured prompting questions to construct a reflective story (Ligrani \& Niewolny, 2017; Lyon et al., 2011; Niewolny \& D'Adamo-Damery, 2016; Peters et al., 2010). The conversations took place on the participant's farm at an agreed-upon, convenient setting. The participants were asked to commit to two farm visits of 2 to 2.5 hours to allow ample time to introduce and discuss the questions for a 60 to 90 -minute semi-structured conversation (Niewolny \& D'Adamo-Damery, 2016). A stipend was provided to acknowledge the participant's time commitment and schedule. Following Niewolny \& D'Adamo-Damery's (2016) process and our university's Institutional Review Board (IRB) guidelines, each narrative collected during the first visit was consented to, audiorecorded, transcribed, re-transcribed with editing, and configured as a public "narrative" through a co-editing process with the farmers and interviewers. The final co-edited narrative of each participant ranged in length from nine to 12 pages. After the conversation, researchers were led on a farm tour to observe soil and water conservation practices that were particularly meaningful and relevant to the farmer's story and could be highlighted in a follow-up two to three-minute video. The followup videos of each participating farmer interviewed for the Soil, Conservation, and Place project are hosted on the Center's website.

\section{Data Analysis}

The narratives as data were analyzed to examine the deeper rhizomatic and mycorrhizal threads that link farmer perspectives and practices to broader food system domains. Whole Measures for Community Food Systems (CFS): Values-Based Planning and Evaluation (Abi-Nader et al., 2009) was used as a dialogical coding framework to better understand and assess these rhizomatic and mycorrhizal intersections and nodes (Saldana, 2016). In the data analysis process, we conducted two rounds of coding in Atlas.ti using the Whole Measures for Community Food Systems fields and practices as a central component of our codebook. Data analysis was based on the frequency and volume of occurrence of references to themes in the transcripts of the narratives (Niewolny \& D'Adamo-Damery, 2016). The themes and sub-themes were specifically articulated and framed by the interviewees and their transcribed narratives. As highlighted in the results section below, this study enabled us to use the whole measures framework to see and understand farmer agroecological knowledge beyond best practices; thus, revealing the ways farmers leverage and extend their broader ecological and sociological ethos of land, natural resource stewardship, and community at an individual and collective level.

\section{Results}

Analysis of the transcribed narratives highlighted the commonalities and complexities of the participating farmers and how farmers construct and contest agroecological knowledge across different social, political, and ecological domains of our food and farming systems. Five primary themes were identified from the narrative inquiry data analysis as intersecting with the values-based whole measures of community food systems (CFS). The primary themes that emerged included: (1) a pledge toward ecological health and intergenerational ethics for small farm viability; (2) the building of diverse and collaborative relationships, trust, and reciprocity 
through farmer to farmer learning and/or community relations; (3) the desire to provide access to healthy, diversified, culturally appropriate foods; (4) the creation of equity and justice through cooperative and emancipatory farming models; and (5) the supporting of livelihoods and social wellbeing by resisting suburban development and an ethos of community care. Excerpts from the nine to 12-page narrative transcripts are highlighted below to showcase study participants' diverse and common perspectives and how their conservation stories are deeply intertwined with other food system values. In addition, farmer's soil and water conservation practices are listed in Table 1.

\section{A pledge toward ecological health and intergenerational ethics for small farm viability} Many study participants credited their long-term success to focusing on the whole measure of sustainable farmland and natural resources and building ecological health from the soil up. As CJ Isbell of Keenbell Farm emphasized, "We think we are cattle farmers, or grain farmers, [but] we're soil farmers." Similarly, cattle farmer Mike Phillips shared his understanding of a soil-first approach to farming by recalling conversations he has had with neighboring farmers:

Dirt is dead. Soil is living. And you got the same soil, but what's happenin' is you've mined it, and what you gotta do is be able to put back...I said, 'You gotta feed the belowground, so you can feed the aboveground. If you don't keep the belowground fed, you're headin' down the wrong road.'

Janet Aardema credits her and her husband's long-term success in farming to their focus on building and conserving soil: “. . . we're half a soil company, and half a logistics company. ... That's what allows us to be rooted here in this community, and really, truly staying in business, carrying out the work of growing food for the community."

For many study participants, soil health is a priority linked to ecological and social sustainability. Danny Boyer described this clear connection in his interview:
I would like to leave a farm that's intact so that someone else can pick up and have the opportunity to produce a good, viable product, taking care of our natural resources along the way. ... I have worked with the Virginia Beginning Farmers and Ranchers, and I mentor with several on a regular basis and encourage people, younger people, to get in farming as a livelihood. I think we'll, as a community and as a nation, we'll be better off to take care of the resources and our land and our water so that we can produce our food.

\section{The building of diverse and collaborative relationships, trust, and reciprocity through farmer to farmer learning and/or community relations}

The whole measures coding framework revealed that building diverse and collaborative relationships, trust, and reciprocity through farmer to farmer learning opportunities and/or community relations intersect with all participants' narratives. The co-creative production and sharing of knowledge, and prioritizing human and social values are consonant with the whole measure of strong communities.

Study participants highlighted informal and formal farmer to farmer learning opportunities as beneficial for farm viability and essential for longterm conservation efforts. In the following excerpt, Phil Witmer described learning from other farmers domestically and internationally:

Every farm we visited is different than ours, but it has been very helpful for me to learn from other people's experiences [and] how they manage in their environment with their challenges.... Some production challenge comes up, and you think of how so-and-so was managing that issue. ... I've always felt that it was really important to share what we're doing because I've benefited so much from what others have done.

Many study participants shared their experiences of participating in on-farm demonstrations of soil conservation practices. Robert Spiers 
explained how the benefits of on-farm demonstrations could extend well beyond the farm itself:

We were approached by an Extension service to do a project for the Ag Expo concerning strip-tilling tobacco... The first year we did the experiment, we did four acres, and the next year we did 17 acres, and the year after that we went $100 \%$...probably $80 \%$ of the tobacco in the county is done strip-till now, which would probably be in the order of eight or nine hundred acres that was done after we carried out the demonstration.

For Danny Boyer, a former employee of the USDA-Natural Resources Conservation Service (NRCS), long-term soil and water resource conservation requires farm demonstrations, education, application, and strong, trusting community relationships:

You're not gonna have an impact just passing laws, but if you do demonstrations and show people what can be done, and then you have education ... and then start doing application. ... That's where you really get to having water quality and sustainable farms. You do have to build relationships, people have to trust you, you have to do what you say you're gonna do.... You need to go back and follow up and help them grow and learn together as peers and colleagues.

CJ Isbell, who described himself as a soil farmer, discussed community relationships as the foundation for long-term farm viability:

It is not just a money transaction between the customer and us, it is developing that relationship because I really feel like for agriculture as a whole, that's one of the voids that's in the marketplace-that distance between the customer and the producer. The connection with the people who are buying our products, that's what creates the lasting relationships, lasting transactions, and sustainability. ... It's a holistic approach that really makes a difference.
Other study participants expressed their commitments to future generations in different ways. For example, Anne Geyer created a young worker training program on AgriBerry Farm as a way to "pay it forward." Anne received the benefits of having incredible mentors as a beginning farmer and wants to pass on her knowledge and experience to the next generation. Similarly, Mike Phillips, in partnership with a local career and technical education center, allowed his farm to be a learning laboratory and student-run farming operation. For Mike, true sustainability is not possible without giving to the next generation and enabling young people to build on current efforts:

I've had people tell me 'you're crazy,' to take a farm and say, 'Okay, it's yours to work with.'. . . I said, 'If it's God's will, it's ok.' You know, it's not me but a gift that has been given to me. When a gift is given, it needs to be given back.... And that's sustainability. Sustainability comes from the harmonious balance ... no matter how high you go in life, degree-wise, you'll never get anywhere without a good mentor.

Ira Wallace is a co-owner and operator of the Southern Exposure Seed Exchange, a workerowned cooperative offering approximately 700 varieties of vegetable, flower, herb, grain, and cover crop seeds in partnership with 70 other farms. Southern Exposure Seed Exchange is committed to implementing environmental conservation practices on its 72 -acre farm through cover cropping, low-till, diversification, and organic certification, while also encouraging and supporting these practices on their partnered and contracted farms.

Beyond environmental conservation, Ira posits that Southern Exposure is here "because of community more than farming," exemplified in their profit-sharing model, farmer support services, and community organizing and educational strategies. With values anchored in justice and fairness, Ira (who grew up during the civil rights movement) believes in the power of ethical food production. Ira shared: "I like to tell young people if they want to take a radical stand in the world become an ethical food producer." 


\section{The desire to provide access to healthy,} diversified, and culturally appropriate foods

Analysis of the narrative transcripts revealed that the desire to provide healthy food for all through their operation intersected with six of the 12 participating farms. These six farms were direct-toconsumer operations. The intersection demonstrates alignment with the agroecological principle of supporting culture and food traditions and ensuring all community members have access to healthy, diversified, and culturally appropriate foods. The examples below highlight various perspectives on how these farmers' ecological ethos is entwined with the whole measure of supporting healthy people.

For Amy Hicks, the drive to overcome the challenges of small-scale farming and care for natural resources is fueled by her strong desire to provide her community with healthy, organic food:

As far as values in our work, we're really keen on organic obviously. We're just very, very interested in producing good, clean, nutritious food for those in our community, and that's what keeps us going each and every day .... is being at the market and seeing these customers we've had for close to 20 years ... We think everybody should eat more vegetables, and if they can, they should definitely eat more organic vegetables.

Comparably, Renard Turner directly spoke to the relationship between human and environmental health. He shared his land stewardship and food access ethos with a particular focus on inclusivity across racial and class lines:

We're concerned with the systemic racism that we know exists and how that pans out across the country. These children are being raised on sub-standard food. They're being raised in environments that are unhealthy.... Our position in life is to leave this land in a better condition than how it was when we found it. ... We would like the world to be a better place for everyone, and I think that one of the ways to do that is to have food equality and access to good food for everyone.
Jonathan McRay spoke to nurturing soil health, healthy people, and social justice. Drawing inspiration from his time at Soul Fire Farm, Jonathan reflected on soil conservation as a mechanism for fostering healthy people:

I hear a lot of white farmers talking about the soil for productivity and soil health, especially out of concern for climate change. I don't disagree with those at all, but at Soul Fire [Farm], with this focus on soil health as a Black-led farm resisting racism and injustice in the food system. One of their primary concerns for soil health is that for the food to be healthy and nutrient-dense, the soil has got to be healthy and full of the nutrients.... That felt like a deep ah-ha moment to me like, 'This is why we take care of soil.'

For Ira Wallace of Southern Exposure Seed Exchange, culturally appropriate foods have historical and emancipatory context. Southern Exposure curates heirloom variety seeds and has undertaken a new project to find information about foods and seeds from the African diaspora, a part of the American experience.

\section{The creation of equity and justice through cooperative and emancipatory farming models} Three narratives specifically intersected with the theme of creating equity and justice through cooperative and emancipatory farming models. The intersection is based on the frequency that equity, just, cooperative, and emancipatory models were mentioned in the conversations and agroecologically enacted through these unique farming operations.

For both Jonathan McRay and Renard Turner, farming as a process and practice can be liberating and healing. Drawing on the natural processes of the forest, Jonathan believes that farming can be a source of holistic remediation and restorative justice to heal ecological and sociological aspects of our world:

For us, those roots grow out of agroforestry, to farm like the forest, watershed health to care for our home and our place, and restorative 
justice. And through those, we're trying to farm like the forest [agroforestry, polyculture] and remediate or heal the toxins that pollute our souls in society and soil, whether that's chemical leaching in the watershed or white supremacy in our institutions and in our bodies.

Renard sees farming, land ownership, and food production as strengthening sovereignty and individual and collective agency, and potential means for the liberation of black and brown communities:

My parents ... felt that, you know, as a black child, that I should be studying something different than agriculture because we needed to get away from farming because of this antiagricultural black-lash that a lot of black folks still have. They equate farming to slavery, and the reality is it's the exact opposite. When you own the land, and you're a farmer, you can really provide for your family in a much better, safer way, generally.

Study participants also shared what cooperative and emancipatory farming models can look like in practice. Jonathan McRay demonstrated justice and fairness through reparations and restitution:

And holding ourselves accountable to making those relationships right, and for us, that looks like redistributing a percentage of what we make from the forest farm every year to movements and groups who have been most violently targeted by the oppressive forces in our country...we see it as a necessary part of reparation, but also as an imitation of the trees who gave away a lot of their photosynthetic energy to the soil that sustains them.

Comparatively, Ira Wallace exercises her values of justice and fairness by supporting partnering farmers through a cooperative seed exchange business model:

I came up during the civil rights movement, and so the importance of trying to live a life that would create a world where everyone could live a good life is really important. ... I know that not everybody is gonna go that far, but we share our money equally. ... I think in farming that it is really a crime and a shame that the farmers get so few of the dollars that go into food. In our seed company, what we try to do is both help our farmers reduce costs and incrementally help them have more of the dollars [ $5 \%$ of the cooperative's seed sales go back to the farmers in addition to what they are initially paid for seed the cooperative purchases from them], the seed dollars that a consumer is paying. ... Those are our kinds of values.

... Just having grown up with all kinds of crazy fruit trees and garden plots right around all, right around the edges, kind of makes having mixed agriculture something important. Just the thought that we should try to live simply, a good life, a good life that everyone can share. Not a fancy rich life that some people have to live like slaves in order for you to have.

\section{The supporting of livelihoods and social well- being by resisting suburban development and an ethos of community care}

Farmers and farming communities are confronted with encroaching suburban development. This theme was mentioned in four of the 12 narratives. These farmers encourage equity and social wellbeing as they face suburban development and resist encroachment. Community care is reflected in the following insights.

Janet Aardema and her husband expressed their social and environmental activism through land stewardship, community care, and social resistance by creating a farm in a rapidly developing urban and suburban region:

Where our priorities shine through is in this decision that we made.... We chose to be on these five acres in a really developed suburban county instead of being on 20 acres in a more agricultural and farther away county.... We think it's important that land be used in 
Chesterfield County to feed the community, rather than just sort of standing by and letting it be okay for more and more land to be paved over. . .

Jonathan McRay recognized that farming connects people to the broader community of living things through an interdependent relationship of deep care and engagement:

But I see the community as I do the watershed, as the actual ecological place and all the creatures that live here. And so, by farming, by growing soil and food, and seeing the flow of water, that to me feels like one of the primary ways to understand what a community is because it's both a sense of belonging but also an act of participation and accountability and responsibility.

Participation, accountability, and responsibility were also reflected by Gerald Garber, a dairy farmer in Augusta County, who decided to allow public regulatory officials and the broader environmental community access to his dairy farm for education and conversations on salient topics like nutrient management, water quality improvement, soil health, natural resources conservation, and ongoing advocacy for Virginia agriculture:

I'm like, "you know what, I can sit at home and complain, or I can try to talk to people." I have people all the time say to me, you let people from the EPA come to your farm? Yep ... if they don't ever see it, how do they know what's going on in the real world?... I'll let anyone in who wants to come in. And I will take my chances that I can justify that what I'm doing is correct.

\section{Discussion and Conclusion}

This narrative-based research of agroecological knowledge inquiry holds implications for our research and practice responses to the mounting social, economic, and ecological crises facing food and farming systems. Sustainability requires researchers and practitioners to go deeper and beyond strict linear thinking. Like rhizomes and mycorrhizae in a plant-soil ecosystem, these narratives help us understand food and farming as an entangled and co-generative system of social and ecological exchanges and associations with soil, food, health, and liberation. Rhizomes and mycorrhizae are agroecological metaphors of relational farmer knowledge networks and exchanges hidden but critical to epistemological possibilities in the food system. We encourage further use of metaphors to shift conversations, disrupt current understanding of relationships, illuminate present paradoxes, and frame future possibilities.

The narrative inquiry approach based on a whole measure dialogical framework allowed us to learn that farmers' lived experiences, values, and relationships are rhizomatic and mycorrhizal in nature. Farmer knowledge like rhizomes have epistemic origins and lateral adventitious roots, enabling us to unearth and better "see" how agroecological knowledge is essential for growth and survival within an ecosystem and how farmers use their knowledge base to engage and contextualize different principles and practices. Similarly, like the relationship of plant roots with mycorrhizae soil fungi, farmers have extensive knowledge networks and hidden associations that require digging deeper into lived experiences to see the symbiotic relationships necessary for knowledge formation.

The public narratives of participating farmers allowed us to conceptualize the constructive generative aspects of farmer agroecological knowledge that are hidden below the surface but formative within our current food systems. Farmers' stories and narratives require investigative digging by researchers and practitioners to uncover hidden epistemological assets. Researchers and practitioners must delve deeper into farmers' stories and narratives to discover how lived experiences, values, and relationships inform principles and practices to achieve just humane ends and create new possibilities. By starting with a conversation about soil, conservation, and place, we learned agroecological knowledge provides different imagery of farmers altogether; farmers' narratives and their expression of agroecological knowledge can challenge dominant research norms, resist stereotyping, and address unjust practices and racialized vulnerabilities in the food system. 
Therefore, we need to reevaluate and rethink how we engage with farmers as educators, movement makers, and practitioners. We must reconsider the notion of best research and management practice to account for lived experiences, values, complexity, depth, and the context of social-eco relationships. Farmers' social-eco relationships are expansive and extensive-like rhizomes and mycorrhizae-but harder to see and account for in agroecological knowledge formation, production, and expression. As demonstrated in Table 1, soil and water conservation practices are easier to count and list in tabular form. Listening and storytelling take more time but are generative research methods that can go below the surface to add depth and texture to the analysis of agroecological knowledge and the adoption and use of these practices. Food systems practitioners and researchers should be encouraged to listen and engage in storytelling and narrative-based research to learn about the socio-political aspects of agroecology and open new relational spaces in food and farming systems. Additionally, our extension and education documents need to focus more on case studies because of the idiosyncratic nature of farmers' stories and their operations rather than generalizable knowledge.

Conceptually, our research aimed to challenge the hegemonic gender-race-class politics of the food system (e.g., Alkon \& Agyeman 2011; Guthman, 2008; Slocum, 2007) and the epistemic politics that agroecology is 'thinly' legitimate (Montenegro de Wit \& Iles, 2016). We specifically recognize how these politics affect our work life and the ability of researchers, extension educators, and practitioners to question working assumptions. Furthermore, these hegemonic and epistemic politics have narrowed vision, so other pathways and lines of flight for food system reform and practice are blocked, made invisible, or erased (Orlie, 2009).

We especially acknowledge the administrative and material demands neoliberal governance and rationality have created for the USDA, Natural Resources Conservation Service, Soil and Water Conservation Districts, and Extension professionals, and how they serve farmers and communities. Neoliberal framing of governance inherently weakens research, limits educators and conservationists' ability to build durable work relationships with farmers, minimizes opportunities for listening, and constrains food and farm system possibilities. Farmers' narratives are living, richly textured, multidimensional in structure and depth, and their influence on principles and practices must be considered. Linear thinking about adoption principles and practices alone is inadequate. We emphasize the following points for application and consideration for research and practice by scholars and scholar-practitioners:

- Support food system practitioners in their efforts to acknowledge the stories and experiences of farmers as critical to knowledge and movement formation. Encourage stories and narrative-based learning approaches in everyday practice, educational documents, and programming.

- Support and participate in narrative, story, and engaged listening research and outreach approaches and methods as a deeper multidimensional inquiry of human and natural systems ecology. For example, a methodology such as a story circle can invite practitioners and researchers to explore dominant discourses; encourage partnerships; and acknowledge potential research and education possibilities.

- Use an agroecological lens to further research the indigenous knowledge of farming communities in Virginia and beyond.

This narrative-based research helps us see how farmer knowledge is constructed in a socialpolitical-cultural context and that knowledge is more than a set of "best practices." The narratives of the 12 farmers reveal the depth of experiences and how their values intersect with soil health, liberation, economic sustainability, and community resiliency. Our research and educational responses to mounting social, economic, and ecological crises must be reevaluated and recontextualized. Today's food and farm system challenges cannot be readily "solved" by technical and 
rational "best practices" but must be embraced with expansive and extensive systems of knowing that are more rhizomatic and mycorrhizal in design and practice, where listening, storytelling, and generative approaches to research are characteristic of agroecological knowledge and systems.

\section{Acknowledgments}

We warmly thank Wade Thomason, Ph.D., and Mike Parrish of Virginia Tech and Virginia Cooperative Extension for their valuable contributions to the project. We also are grateful to the participating farmers for sharing their time, experiences, and insights with us and the broader community.

\section{References}

Abi-Nader, J. A., Harris, A., Herra, K., Eddings, H., Habib, D., Hanna, J., Paterson, C., Sutton, K., \& Villanuesva, L. (2009). Whole measures for community food systems: Value-based planning and evaluation. Center for Whole Communities. http://foodsecurity.org/pub/WholeMeasuresCFS-web.pdf

Alkon, A., \& Agyeman, J. (Eds.). (2011). Cultivating food justice: Race, class, and sustainability. MIT Press. https://doi.org/10.7551/mitpress/8922.001.0001

Altieri, M. A. (2000). Developing sustainable agricultural systems for small farmers in Latin America. Natural Resources Forum, 24(2), 97-105. https://doi.org/10.1111/j.1477-8947.2000.tb00935.x

Arnold, R. D., \& Wade, J. P. (2017). A complete set of systems thinking skills. Insight, 20(3), 9-17. https://doi.org/10.1002/inst.12159

Brook, R. K., \& McLachlan, S. M. (2008). Trends and prospects for local knowledge in ecological and conservation research and monitoring. Biodiversity and Conservation, 17(14), 3501-3512. https://doi.org/10.1007/s10531-008-9445-x

Carr, A., \& Wilkinson, R. (2005). Beyond participation: Boundary organizations as a new space for farmers and scientists to interact. Society and Natural Resources, 18(3), 255-265. https://doi.org/10.1080/08941920590908123

Church, S. P., Lu, J., Ranjan, P., Reimer, A. P., \& Prokopy, L. S. (2020). The role of systems thinking in cover crop adoption: Implications for conservation communication. Land Use Policy, 94, 104508. https://doi.org/10.1016/j.landusepol.2020.104508

Clandinin, D. J. (2007). Handbook of narrative inquiry: Mapping a methodology. Sage Publications. https://doi.org/10.4135/9781452226552

Clandinin, D. J., \& Connelly, F. M. (2000). Narrative inquiry: Experience and story in qualitative research. Jossey-Bass.

Creswell, J. W. (2008). Educational research: Planning, conducting, and evaluating quantitative and qualitative research (3rd Ed.). Pearson Education.

Deleuze, G., \& Guatarri, F. (1987). A thousand plateaus: Capitalism and schizophrenia (B. Massumi, Trans.). University of Minnesota Press. (Original work published 1980.)

DuPuis, E. M., Harrison, J. L., \& Goodman, D. (2011). Just food. In A. Alkon \& J. Agyeman (Eds.), Cultivating food justice: Race, class, and sustainability (pp. 283-307). MIT Press.

Evert, R. F. (2006). Esau's plant anatomy: Meristems, cells, and tissues of the plant body: Their structure, function, and development (3rd Ed.). John Wiley \& Sons. https://doi.org/10.1002/0470047380

Forester, J. F. (1999). The deliberative practitioner: Encouraging participatory planning processes. MIT Press.

Galt, R. E. (2016). The relevance of Regional Political Ecology for agriculture and food systems. Journal of Political Ecology, 23(1), 126-133. https://doi.org/10.2458/v23i1.20184

Gliessman, S. (2017). Agroecology: Building an ecological knowledge-base for food system sustainability. Agroecology and Sustainable Food Systems, 41(7), 695-696. https://doi.org/10.1080/21683565.2017.1335152

Gliessman, S. (2018). The co-creation of agroecological knowledge. Agroecology and Sustainable Food Systems, $42(1), 1$. https://doi.org/10.1080/21683565.2017.1289727

Guthman, J. (2008). Bringing good food to others: Investigating the subjects of alternative food practice. Cultural Geographies, 15, 431-447. https://doi.org/10.1177/1474474008094315

Hassanein, N. (1999). Changing the way America farms: Knowledge and community in the sustainable agriculture movement. University of Nebraska Press. 
Holt-Giménez, E. (2006). Campesino a campesino: Voices from Latin America's farmer to farmer movement for sustainable agriculture. Food First Books.

Holt-Giménez, E., \& Altieri, M. A. (2013). Agroecology, food sovereignty, and the new green revolution. Agroecology and Sustainable Food systems, 37(1), 90-102. https://doi.org/10.1080/10440046.2012.716388

Karlen, D. L., \& Rice, C. W. (2015). Soil degradation: Will humankind ever learn? Sustainability, 7(9), $12490-12501$. https://doi.org/10.3390/su70912490

Kirschenmann, F. L. (2010). Cultivating an ecological conscience: Essays from a farmer philosopher (C. L. Falk, Ed.). The University Press of Kentucky.

Laforge, J. M. L., \& Levkoe, C. Z. (2018). Seeding agroecology through new farmer training in Canada: Knowledge, practice, and relational identities. Local Environment, 23(10), 991-1007.

https://doi.org/10.1080/13549839.2018.1515901

Lal, R. (2016). Soil health and carbon management. Food and Energy Security, 5(4), 212-222. https://doi.org/10.1002/fes3.96

Law, J. (2008). On sociology and STS. The Sociological Review, 56(4), 623-649. https://doi.org/10.1111/j.1467-954X.2008.00808.x

Laws, L. (2017). Agricultural sustainability: Five Midwestern row crop farmers share their views. Journal of Soil and Water Conservation, 72(3), 53A-58A. https://doi.org/10.2489/jswc.72.3.53A

Ligrani, R., \& Niewolny, K. (2017). Community food work as critical practice: A faith-based perspective through narratives. Journal of Agriculture, Food Systems, and Community Development, 7(4), 61-77. https://doi.org/10.5304/jafscd.2017.074.001

Lyon, A., Bell, M. M., Gratton, C., \& Jackson, R. (2011). Farming without a recipe: Wisconsin graziers and new directions for agricultural science. Journal of Rural Studies, 27(4), 384-393. https://doi.org/10.1016/i.jrurstud.2011.04.002

Magdoff, F., \& van Es, H. (2010). Building soils for better crops: Sustainable soil management, Third edition. Sustainable Agriculture Research and Education (SARE) Handbook Series 10.

Méndez, V. E., Bacon, C. M., \& Cohen, R. (2012). Agroecology as a transdisciplinary, participatory, and action-oriented approach. Agroecology and Sustainable Food Systems, 37(1), 3-18. https://doi.org/10.1201/b19500-2

Montenegro de Wit, M. (2021). What grows from a pandemic? Toward an abolitionist agroecology. The Journal of Peasant Studies, 48(1), 99-136. https://doi.org/10.1080/03066150.2020.1854741

Montenegro de Wit, M., \& Iles, A. (2016). Toward thick legitimacy: Creating a web of legitimacy for agroecology. Elementa: Science of the Anthropocene, 4, 000115. https://doi.org/10.12952/journal.elementa.000115

Neef, A., \& Neubert, D. (2011). Stakeholder participation in agricultural research projects: A conceptual framework for reflection and decision-making. Agriculture and Human V alues, 28(2), 179-194. https://doi.org/10.1007/s10460-010-9272-z

Niewolny, K. L., \& D’Adamo-Damery, P. (2016). Learning through story as political praxis: The role of narratives in community food work. In J. Sumner (Ed.), Learning, food, and sustainability: Sites for resistance and change (pp. 113-131). Palgrave/Macmillan. https://doi.org/10.1057/978-1-137-53904-5 7

Orlie, M. A. (2009). There is no alternative. Theory \& Event, 12(2). https://doi.org/10.1353/tae.0.0064

Peters, S. J., Grégoire, H., \& Hittleman, M. (2004). Practicing a pedagogy of hope: Practitioner profiles as tools for grounding and guiding collective reflection in adult, community, and youth development education. In M. Reynolds \& R. Vince (Eds.), Organizing Reflection (pp. 1-26). Ashgate.

Peters, S. J., Alter, T. R., \& Schwartzbach, N. (2010). Democracy and higher education: Traditions and stories of civic engagement. Michigan State University Press.

Pimbert, M. P. (Ed.). (2017). Food sovereignty, agroecology and biocultural diversity: Constructing and contesting knowledge. Routledge. https://doi.org/10.4324/9781315666396

Pimbert, M. P. (2018). Global status of agroecology: A perspective on current practices, potential and challenges.

Economic and Political Weekly, 53(41), 52-57.

https://www.agroecologynow.com/wp-content/uploads/2018/10/EPW-Agroecology-Michel P Pimbert2.pdf 
Pretty, J. (2002). People, livelihoods and collective action in biodiversity management. In T. O'Riordan \& S. StollKleemann (Eds.), Biodiversity, Sustainability and Human Communities: Protecting Beyond the Protected (pp. 61-86). Cambridge University Press. https://doi.org/10.1017/CBO9780511492655.005

Richmond, H. J. (2002). Learners' lives: A narrative analysis. The Qualitative Report, 7(3), 1-14. https://nsuworks.nova.edu/tqr/vol7/iss3/4

Saldana, J. (2016). The coding manual for qualitative researchers (3rd ed.) Sage.

Schon, D. A. (1983). The reflective practitioner: How professionals think in action. Basic Books.

Slocum, R. (2007). Whiteness, space and alternative food practices. Geoforum, 38(3), 520-533. https://doi.org/10.1016/i.geoforum.2006.10.006

Stepney, P. (2006). Mission impossible? Critical practice in social work. The British Journal of Social Work, 36(8), 12891307. https://doi.org/10.1093/bjsw/bch388

Sylvia, D. (2005). Mycorrhizal symbiosis. In D. M. Sylvia, P. G. Hartel, J. J. Fuhrmann, \& D. A. Zuberer (Eds.), Principles and applications of soil microbiology (2nd ed., pp. 263-282). Pearson Prentice Hall.

Tedersoo, L., Bahram, M., \& Zobel, M. (2020). How mycorrhizal associations drive plant population and community biology. Science, 367(6480), Article eaba1223. https://doi.org/10.1126/science.aba1223

Thompson, N., \& Pascal, J. (2012). Developing critically reflective practice. Reflective Practice, 13(2), 311-325. https://doi.org/10.1080/14623943.2012.657795

U.S. Department of Agriculture, Natural Resources Conservation Service [USDA NRCS]. (2018). Soil health in Virginia: The next frontier of conservation. https://www.nrcs.usda.gov/wps/portal/nrcs/detailfull/va/soils/health/?cid=stelprdb1248422

Virginia Tech Center for Food Systems and Community Transformation. (2021). Soil, Conservation, and Place project. https://foodsystems.centers.vt.edu/projects1/SoilConservationandPlace.html

Zimdahl, R. L. (2006). Agriculture's ethical horizon. Elsevier. 